Conclusion* We have developed the first robust model of disease-specific survival after recurrence stratifying relapsing cervical cancer patients according to their risk profile using six traditional prognostic markers. The strongest factor related to the length of post-recurrence survival was the largest size of the primary tumour, followed by the presence of symptoms at the time of diagnosis, which remained significant even after correction for lead-time bias.

\section{SENSITIVITY AND FALSE NEGATIVITY OF SLN FROZEN SECTIONHISTOLOGICAL EVALUATION IN THE SENTIX TRIAL (CEEGOG-CX01; ENGOT-CX2; NCT02494063)}

${ }^{1} \mathrm{R}$ Kocian*, ${ }^{2} \mathrm{C}$ Kohler, ${ }^{1} \mathrm{~S}$ Bajsová, ${ }^{1} \mathrm{~S}$ Sebestova, ${ }^{3} \mathrm{I}$ Zapardiel, ${ }^{4} \mathrm{GDI}$ Martino, ${ }^{5} \mathrm{~L}$ Van Lonkhuijzen, ${ }^{1} \mathrm{~B}$ Sehnal, ${ }^{3} \mathrm{O}$ Arencibia Sanchez, ${ }^{3} \mathrm{~B}$ Gil-Ibanez, ${ }^{4} \mathrm{~F}$ Martinelli, ${ }^{1} \mathrm{~J}$ Presl, ${ }^{1} \mathrm{~L}$ Minar, ${ }^{1} \mathrm{R}$ Marek, ${ }^{6} \mathrm{P}$ Kascak, ${ }^{1} \mathrm{P}$ Havelka, ${ }^{1} \mathrm{M}$ Michal, ${ }^{7} \mathrm{~T}$ Van Gorp, ${ }^{1} \mathrm{~K}$ Nemejcova, ${ }^{1}$ D Cibula. ${ }^{1}$ Czech Republic; ${ }^{2}$ Germany; ${ }^{3}$ Spain; ${ }^{4}$ Italy; ${ }^{5}$ Netherlands; ${ }^{6}$ Slovakia; ${ }^{7}$ Belgium

\subsection{6/ijgc-2021-ESGO.79}

Introduction/Background* SENTIX is a prospective cohort multicentric international study on sentinel lymph node (SLN) biopsy without pelvic lymph node dissection (PLND) in patients with early-stage cervical cancer. SLN frozen section (FS) and pathological ultrastaging were mandatory by the protocol. Samples from SLN were reviewed centrally for pathological assessment quality control. Only sites experienced in SLN biopsy technique could join the trial.

Methodology In total, 47 sites from 18 countries participated in the trial. Patients with FIGO 2009 stages T1A1/LVSI+ T1B1 $(<4 \mathrm{~cm}$ or $\leq 2 \mathrm{~cm}$ for fertility sparing), with common tumour types and no suspicious lymph nodes on imaging were

\section{Abstract 950 Table 1 Patient's characteristics $(\mathrm{N}=733)$}

\begin{tabular}{|c|c|c|}
\hline \multicolumn{2}{|l|}{ Parameter } & \multirow{2}{*}{$\begin{array}{c}\mathrm{N}(\%) / \text { median }\left(5-95^{\text {th }}\right. \\
\text { percentile) }\end{array}$} \\
\hline Age & & \\
\hline & $\leq 40$ & $294(40.1 \%)$ \\
\hline & $41-60$ & $339(46.2 \%)$ \\
\hline & $61+$ & $100(13.6 \%)$ \\
\hline \multirow[t]{4}{*}{ BMI } & $\leq 25$ & $418(57.0 \%)$ \\
\hline & $25-30$ & $169(23.1 \%)$ \\
\hline & $30+$ & $141(19.2 \%)$ \\
\hline & NA & $5(0.7 \%)$ \\
\hline \multirow[t]{2}{*}{ ECOG PS } & 0 & $704(96.0 \%)$ \\
\hline & 1 & $29(4.0 \%)$ \\
\hline \multirow[t]{3}{*}{ Diagnostic method } & Biopsy & $331(45.2 \%)$ \\
\hline & Conization & $399(54.4 \%)$ \\
\hline & NA & $3(0.4 \%)$ \\
\hline \multicolumn{3}{|c|}{ Enrolled patients by site's size: } \\
\hline & $\leq 10$ & $126(17.2 \%)$ \\
\hline & $21-20$ & $81(11.1 \%)$ \\
\hline & $21+$ & $526(71.8 \%)$ \\
\hline \multirow{2}{*}{$\begin{array}{l}\text { Maximum preoperative } \\
\text { tumour size }(\mathrm{mm})\end{array}$} & $\leq 20$ & $471(64.2 \%)$ \\
\hline & $20.1-40$ & $262(35.8 \%)$ \\
\hline Preoperative tumour stage & $1 \mathrm{~A} 1$ & $32(4.4 \%)$ \\
\hline \multirow[t]{2}{*}{ (FIGO 2009) } & $1 \mathrm{~A} 2$ & $54(7.4 \%)$ \\
\hline & 1B1 & $647(88.2 \%)$ \\
\hline \multirow[t]{4}{*}{ Tumour grade } & G1 & $179(24.4 \%)$ \\
\hline & G2 & $373(50.9 \%)$ \\
\hline & G3 & $157(21.4 \%)$ \\
\hline & NA & $24(3.3 \%)$ \\
\hline LVSI & yes & $448(61.1 \%)$ \\
\hline \multirow[t]{4}{*}{ Tumour type } & SCC & $508(69.3 \%)$ \\
\hline & $\mathrm{AC}$ & $210(28.6 \%)$ \\
\hline & AS & $9(1.2 \%)$ \\
\hline & NA & $6(0.8 \%)$ \\
\hline Excluded: & & $83(11.2 \%)$ \\
\hline \multirow{2}{*}{ Preoperatively } & Surgery cancelled & $4(0.5 \%)$ \\
\hline & ICF withdrawn & $4(0.5 \%)$ \\
\hline \multirow[t]{2}{*}{ Intraoperatively } & SLN not detected bilaterally & $55(7.5 \%)$ \\
\hline & $>1 \mathrm{~B} 1$ & $12(1.6 \%)$ \\
\hline Other & & $8(1.1 \%)$ \\
\hline
\end{tabular}

Abstract 950 Table 2 SLN status assessed by frozen section and final ultastaging $(\mathrm{N}=650)$

\begin{tabular}{ccccccc}
\hline \hline \multirow{2}{*}{$\begin{array}{c}\text { Type of SLN } \\
\text { involvement }\end{array}$} & \multicolumn{2}{c}{ SLN status (No. of patients) } & \multicolumn{4}{c}{ SLN frozen section outcome (\%) } \\
\cline { 2 - 7 } & $\begin{array}{c}\text { Frozen } \\
\text { section }\end{array}$ & Ultrastaging & $\begin{array}{c}\text { Final SLN } \\
\text { status* }\end{array}$ & Sensitivity & $\begin{array}{c}\text { False } \\
\text { negativity }\end{array}$ & NPV \\
\hline MAC & 44 & 9 & 53 & $83.0 \%$ & $17.0 \%$ & $98.5 \%$ \\
MIC & 4 & 26 & 30 & $13.3 \%$ & $86,7 \%$ & $95.7 \%$ \\
ITC & 0 & 19 & 19 & $0.0 \%$ & $100,0 \%$ & $96.8 \%$ \\
MAC + MIC & 48 & 35 & 83 & $57.8 \%$ & $42,2 \%$ & $94.2 \%$ \\
MAC + MIC + ITC & 48 & 54 & 102 & $47.1 \%$ & $52.9 \%$ & $91.0 \%$ \\
\hline
\end{tabular}

registered in the trial. Patients remained in the trial after the surgery if SLN were detected on both sides of the pelvis and if SLN were negative on FS histological evaluation. Blue dye, radioactive tracer, indocyanine green or their combinations were all eligible tracers for SLN detection. Intraoperative SLN pathological processing consisted of SLN examination in one randomly selected slice. SLN ultrastaging protocol included a complete processing of all SLN tissue in slices of $2 \mathrm{~mm}$ thickness, 2 sections in $150 \mu \mathrm{m}$ from each block until no tissue left, one stained with H\&E and second examined immunohistochemically.

Result(s)* Altogether 733 patients were registered until Sentix enrolment closure in October 2020, 83 patients were excluded (table 1) and 650 patients was analysed. Patients` characteristics are shown in table 1 . Bilateral SLN detection rate reached 95\%. FS detected macrometastases (MAC) in 44 cases and micrometastasis (MIC) in 4 cases. SLN ultrastaging found additional 9 cases with MAC, 26 with micrometastases (MIC) and all 19 cases with isolated tumor cells (ITC). Sensitivity of FS was $83.0 \%$ for the detection of MAC, $57.8 \%$ for $\mathrm{pN} 1$ status (MAC or MIC) and $47.1 \%$ for any type of SLN involvement (MAC, MIC, ITC). Table 2.

Conclusion* High bilateral detection rate of $95 \%$ was achieved in Sentix sites experienced in the SLN biopsy technique. Intraoperative pathological assessment of SLN failed to detect majority of MIC (86.7\%), all cases with ITC and $42.2 \%$ with pN1 (MIC or MAC).

\section{WATER-JET DISSECTION IN NERVE-SPARING RADICAL HYSTERECTOMY: POSTOPERATIVE OUTCOMES}

S Mukhtarulina*, M Meshkova, O Trushina, H Maltsagova, E Novikova. P.A. Hertsen Moscow Oncology Research Center - branch of FSBI NMRRC, the department of gynecologic oncology, Moscow, Russian Federation

\subsection{6/ijgc-2021-ESG0.80}

Introduction/Background* The development of a nerve-sparing technique of radical hysterectomy leads to a significant functional improvement after surgical treatment of cervical cancer. However, the risk of nerve fibers damage remains high because of difficulties in recognition of elements of the autonomic nervous system. One of approaches for precise nerve dissection is tissue-selective dissection with a water-jet. The main advantage of this method is selective dissection and preservation of nerve fibers and vessels with minimal deformation of the surrounding tissue. This study was aimed to evaluate 